\title{
Agro Informatics Emphasizing its Potentiality as a Full-Fledged Degree Programs: International Context and Indian Potentialities
}

\author{
P. K. Paul ${ }^{1}$, R. R. Sinha ${ }^{2}$, P. S. Aithal ${ }^{3}$, Ricardo Saavedra ${ }^{4}$ and Bashiru Aremu ${ }^{5}$ \\ ${ }^{1}$ Executive Director, MCIS, Department of CIS, Information Scientist (Offg.), Raiganj University, India \\ ${ }^{2}$ Pro Vice-Chancellor (Asian Region), Commonwealth Vocational University, Kingdom of Tonga, Oceania \\ ${ }^{3}$ Vice-Chancellor, Srinivas University, Karnataka, India \\ ${ }^{4}$ Director \& Chair, International Inter-University Programs, Azteca University, México, North America \\ ${ }^{5}$ Vice-Chancellor, Crown University, Intl. Chartered Inc. (CUICI) Argentina Campus, South America \\ E-mail: pkpaul.infotech@gmail.com
}

\begin{abstract}
Agricultural Informatics or Agricultural Information Science is the combination of two major and important subject's viz. 'Agricultural Science' and 'Informatics/Information Science'. This is an interdisciplinary subject and importantly the two major branches from which this is evolved is also bearing interdisciplinary nature. The uses of IT, Computing, or general scientific Documentation is common in almost all the areas and subjects; and as far as agriculture is concerned the documentation and general information management principles were common initially. Gradually like other subjects, Agricultural Informatics also become developed as a field of practice to cater to the need of Agricultural sectors by providing information, IT and technological support. There are various reasons for the introduction of Agricultural Informatics. Initially, it was responsible for information management activities related to the Agriculture and allied areas. Gradually this is become more applied and with diverse in nature. In pre-production activities to postproduction, Agricultural Informatics today become an important practicing field and as well as a field study in major international universities. Even in many developing countries like in India also Agricultural Informatics become a field of study. The field is available with this nomenclature and in other allied nomenclatures. In some context it is noted that the field is available only in some of the streams viz. science or technology, and in some context as a specialization. However, there is a potentiality in offering the field Agricultural Informatics as a branch in other areas, both Indian and International context. This paper is conceptual in nature and deals with such potentialities with a brief overview on Agricultural Informatics including evolution, features and role, and importance.
\end{abstract}

Keywords: Agricultural Informatics, Agro ICT, Universities, Degrees, Interdisciplinary Sciences, Agriculture, IC4DT

\section{INTRODUCTION}

Agricultural Informatics helps in practicing of agricultural production and further activities by various technologies, methods, tools, etc in farming as well as in various agricultural activities. According to expert cultivation is considered, farming in a small area and ideally consider as the need for a family production only whereas, agriculture is involved in a large place [1], [10], [24]. Moreover, it is considered as a commercial intensive and deals with a variety of components viz. plants, seed and corps, animals, etc with the help of miscellaneous methods and therefore also called as Industrial Agriculture. Information Technology (including informatics and management) applications become a common activity in the recent past in diverse areas of agriculture. However, this branch is also applicable in other areas and allied fields viz. horticulture, veterinary sciences, geography, etc. Technology, Information, and management techniques normally treated as important in healthy and better Agricultural Informatics practice. Information and similar content are treated as important in development activities and in Agriculture also this plays a leading role [2], [5], [25]. In the recent past, Agricultural Informatics has started wide practice in developed countries, and as a result, many universities internationally started programs on Agricultural Informatics. Even in some developing nations also started practicing Agricultural Informatics and the academic programs on this very relevant branch. Apart from the Agricultural Informatics nomenclature it is started in other domains viz

1. Agricultural Information Technology,

2. Agricultural Information Systems

3. Smart Agriculture

4. Agricultural Data Sciences, etc.

This trend is in Agricultural Informatics and allied areas are going on rapid stage in many institutions in the current past.

\section{OBJECTIVES}

This paper entitled, 'Agro Informatics with reference to its potentiality as full-fledged educational programs-A Policy Work' is theoretical and policy-based work and deals with following (but not limited to)

1. To get the knowledge on Informatics and allied branches viz. Computer Science, Computer Applications, Information Technology, and other allied nomenclature.

2. To learn about very basics and emergence and types of the Agricultural Sciences, briefly. 
3. To know about the features, functions, and role of Agricultural Informatics in general as well as emerging context.

4. To get the emerging applications of Agricultural Informatics in the agricultural and similar activities.

5. To get on academic programs on Agricultural Informatics as well as in allied areas and nomenclature in India and aboard.

6. To proposed possible academic programs on Agricultural Informatics in different branches as a full-fledged one.

7. To know a brief on issues, challenges regarding the Agricultural Informatics in industries/ practices as well as in academics.

\section{AGRICULTURAL INFORMATICS: THE FOUNDATION, FEATURES AND NATURE}

Informatics is the study and practice of information that deals with the various information activities viz. collection, selection, organization, processing, management, dissemination, etc. Here various IT components are used to reach the goal. Whereas Information Science is synonymous with Informatics in most cases and considered mainly as a subject. Information Technology is also similar to the Informatics but strongly associated with the core of technologies (viz. database technologies, networking technologies, web technologies, multimedia technologies, etc); without the concentration of information. Computer Science is responsible for the design and development of the computer systems and Computer Application in design and development of the applications, and software. Hence in Agricultural field, Informatics/ Information Science play a leading role [6], [9], [18], [26].

Agricultural Informatics is one of the emerging subjects and becomes a field of study in many international universities. Initially, only Agricultural Documentation was the subject, but gradually other branches emerged. The field Agricultural Informatics is supported by various technologies such as viz. database technologies, networking technologies, web technologies, multimedia technologies, etc. And this is changing rapidly day by day. This branch deals with various features and natures and among these few important are includes (but not limited to)

1. Agricultural Informatics as the interdisciplinary subject is associated with subjects like horticulture, veterinary sciences, ecology, Computer Science, Computer Engineering, IT, Information Science, etc.

2. The field of Agricultural Informatics holds the nature of technological, social, ecological studies.

3. Agricultural Informatics is dedicated to the agro business promotion; and hence having the nature of Managerial and Commercial, etc [7], [12], [30].

4. Information or knowledge or data, etc treated as most important and practiced in Agricultural activities including techno supported works. In pre and postproduction of Agricultural works, this field becomes useful.

5. Due to nature and key job/ roles, uses of various tools; in the Agricultural Informatics Engineering Sciences become an important subject.

6. Various kinds of technologies such as computational systems/ technologies and information technology are treated as important in Agricultural Informatics practice. Hence it is various technology dependent.

7. Agricultural Informatics is emerging for making advanced and smart agricultural systems empowered by the technologies. Hence it is changing nature including nomenclatures.

8. Various emerging areas and technologies making Agricultural Informatics become more applied in nature and here various technologies viz. Cloud Computing and Technologies, Robotics and AI, Green Computing and Systems, Data Analytics etc are playing an important role.

9. Professional's aspects and engagement in the Agricultural Informatics are common in current time and thus the skills are play an important role to reach the goal of Agricultural Informatics.

10. Agricultural Informatics plays a leading role in societal development and it is too much socially touched fields and promotion in different means. Hence it holds the nature of social sciences as well.

11. Ecology: directly and indirectly associated with the Agricultural Informatics and allied subjects and it is needed in better healthy and natural farm management and complete sustainable development.

12. Most of the Agricultural activities are these days technology depended and lies on management, etc. The technologies of Agricultural Informatics are also changing; therefore, Agricultural Informatics needs healthy manpower development nature.

Agricultural Informatics is required in the building of modern and healthy Agricultural practices. However, it is important to note that there is a shortage in proper awareness, policy framework as well as governmental supports in the introduction of the Agricultural Informatics branch, etc for the health promotion of the Agricultural Informatics systems in a territory or nation [8], [11], [23].

\section{ROLE OF AGRO INFORMATICS AND ACADEMIC PROGRAMS}

Agricultural Informatics is gaining popularity in different educational institutes ranging from universities, colleges, research centers and even training centers due to its role. As we are aware that, Agriculture is an important concern for social development, and it leads to the economic development and growth of the nation or territory. Around the world, about $70 \%$ of peoples are living with agricultural professions and activities and among these few are directly associated whereas few are indirectly. Agriculture deals with various kinds of affairs, stakeholders, components and in all such facets Agricultural Informatics can be used 
widely. Apart from the developed nations and territories viz. UK, Japan, and United States many other developing countries as well started the academic and training programs on Agricultural Informatics and allied areas due to various jobs and roles viz.

It is important to note that today millions of peoples are associated with agriculture and cultivations and most of them are having minimum skills that help in higher production of agro products, etc. It is noted that till most of the professionals in this field are unable in the operation of Information Technologies in the Agriculture and allied areas. Proper and scientific strategy can help in cultivation with the concern of the heat, cold, flood, drought, insect, pest infestations, disease, weather, etc. Importantly, Agricultural Informatics is an important tool in the development and operation of such activities perfectly. Moreover, apart from the above-mentioned areas the field Agricultural Informatics practices in the Agricultural can also help in knowing of food habits, nutritional aspects, postproduction, business and commercial aspects, ecological aspects etc. Moreover, it helps in the activities of the Agricultural and cultivation efficiency, it minimizes the reduction of cost, minimizes the usages of resources, keep, and enhance automation, etc [3], [16], [32]. Agricultural Informatics or similar subjects however ultimately will help in the following activities.

\section{A. Enhanced Productivity and Effective Operations}

Agricultural Informatics is helping in monitoring, decisions making by the uses of Information Technologies including the AI \& Expert Systems, etc for various kind of operations viz. irrigation, uses of fertilizer, intelligent and machinebased harvesting, climate prediction, etc. Hence ultimately these will be helpful in enhancing Agricultural productivity as well as effective operations in agriculture and allied activities.

\section{B. Expansion of Scale}

Agricultural Informatics is helpful in the better practice of Agricultural operation and this is ultimately enhanced agriculture in more expansion and scaling. The Agricultural Informatics thus needed to bring wider areas [13] [17], [27].

\section{Reducing Resource}

Optimization uses of sensors, advanced information technology components, etc helps in water, energy, land, etc and thus with limited resources, agricultural operation becomes easy and possible effectively.

\section{Cleanliness}

Agricultural Informatics become useful in cleanliness including the management of pesticides, fertilizers, improving precision farming (water and energy, etc). With Agricultural Informatics applications, the green strategy is possible easily. Organic Agriculture will also be promoted by the assistance of this branch over the conventional agricultural methods.

\section{E. Faster and Easiest Agricultural Systems}

By the uses of Agricultural Informatics, the real-time monitoring become possible with IT and various emerging technologies such as Cloud Computing and Technologies, Robotics and AI, Human Computer Interactions, Big Data Management, etc. Thus, various pre-cultivation activities (weather, humidity. Health of crop, soil may also be possible to know) can be possible easily by Agricultural Informatics practice [14], [19], [31].

\section{F. Quality and Quantity based Production}

Agricultural Informatics practice uses various tools including sensors, AI based systems including aerial drone monitoring systems and in crops production (rainfall, humidity, wind condition including speed, pest infestation, soil condition) and management also. Hence, quality of Agricultural products including the food products, plants, corps, etc are possible with Agricultural Informatics practice.

In addition, the above, Agricultural Informatics is helping in Energy management (hence it is useful in agricultural sectors viz. bulbs, televisions, network devices, Analytics devices, drones, switches, etc). Thus, from the above, it is noted that Agricultural Informatics is applicable in diverse areas and places [15], [20], [28].

\section{MANPOWER VS. AGRICULTURAL INFORMATICS}

Agricultural Informatics is dedicated for the advancement and development of activities by the uses of various kinds of technologies, tools and methods, etc in various kinds of pre cultivation, post cultivation as well as agricultural business affairs viz. supply chain management, marketing management, etc. Different universities internationally have started academic programs in this field and as well as other branches viz.

1. Agricultural Information Technology

2. Agricultural Information Systems

3. Agricultural Computing

4. Smart Agriculture

5. Digital Agriculture, etc.

All these programs have started at different levels viz. Bachelors, Masters, and Doctoral. In India, the branch is available in science and engineering in both streams. While there are potentialities to start the programs in other levels such as

1. Certificate Programs

2. Diploma Programs 
3. Advanced Certificate Programs

4. Advanced Diploma Programs

5. Post Graduate Certificate

6. Post Graduate Diploma

7. Masters Certificate

8. Masters Diploma, etc.

Agricultural Informatics as skill-based field can be offered in educational institutes and even in business houses or commercial organizations or industries related to the agriculture and allied fields [14], [21], [22]. Agricultural Informatics is gaining popularity at Master's and Research level due to various reasons such as

1. To get well-rounded, inclusive knowledge as well understanding of the field with special reference to its uses and advancement of the field by education and research.

2. To learn the practical IT and Computing applications in the areas of Agricultural Sciences by the uses of various methods, tools such as IoT systems, sensor systems, etc.

3. Agricultural Informatics masters and higher degree holders are required to design, development as well as implementation of the Agricultural Technologies for the better and healthy agro based operations.

4. Higher degree holders (mainly masters, bachelors, research programs) in Agricultural Informatics can gets a strong understanding in allied areas viz. horticulture, ecology, forestry.

5. Bachelor programs especially the BTech/BE/BS may be helpful in gaining of strong practical skills for the healthy pre and post agro related works using technologies.

6. Masters, Agricultural Informatics programs in concentrated with business and commerce will be helpful in knowing healthy industries in Agriculture and allied sectors.

7. Doctoral programs (by thesis or by publication or by professional portfolio) is helpful in planning, policy implementation and work related to the framework, etc in Agricultural Informatics practice and allied areas.

Internationally many organizations as well as educational institutes including the training centers are established and this trend is growing rapidly. In the development of agricultural activities as well as Agricultural Informatics is valuable. Professionals and students from other allied fields viz. horticulture, ecology, forestry, geography, etc even can join Agricultural Informatics and related programs. As with this subject, technological and computational activities move a more sophisticated manner, so not only in modern and developed nations, Agricultural Informatics can be a field of study in other developing and undeveloped nations as well. In this context, Agricultural Informatics is important at various streams of UG, PG, and Research Programs. The advanced and smarter Agricultural systems no doubt depend on skilled manpower and in this context the degree programs will be more suitable. Similar to the developed countries, Agricultural Informatics can be offered as a full-fledged degree in the developing nations as well. Moreover, apart from the exact nomenclature, this is maybe offered in other emerging nomenclature as well. In India, Agricultural Informatics is offered at Bachelors, Masters level mainly and mostly with Engineering streams. In Agricultural Informatics or allied programs, there are many potentialities to introduce research components. However, in a basic degree, few important gradients are including

1. Basics of the Agricultural Science,

2. Fundamentals of Engineering Sciences,

3. Basics of Information Technology and Computing

4. GIS \& RS in Agricultural Sciences.

5. Basics of Management and Communications, etc.

However, a sample curriculum is mentioned herewith of Shobhit University, Meerut, India with a degree on MTech (Agricultural Information Technology).

For the capability building and entrepreneurship development Government of India is also started different initiative viz.

1. Digitalized Agriculture-This includes Digital Technology as well as the Innovation in Agriculture and allied areas.

2. Agricultural Promotion through the mission and project called-Digital India, make in India, Skill India and Start Up India, etc.

3. Digitalized Agro-It is another effort deal with the Agricultural Risk Management Solution, etc.

4. Digitalised Access in various sorts and means viz. Inputs, Technology, Knowledge, Skill, Agricultural Finance, Credit, Marketing and Agribusiness Management, to Farmers, etc [16], [28], [29].

It is worthy to note that the universities in these categories are mainly from Agricultural universities and Professional Universities; and importantly most are private in nature. Some of the universities that offer Agricultural Informatics programs are depicted in Table II. From the study, it is been noted that there is a gap in offering Agricultural Informatics or allied programs in public institutes. Another important policy can be introducing Agricultural Informatics as a program in Engineering and Technological Universities, as India holds many institutes in this category with BTech/BE/MTech/ME, etc in Agricultural Informatics or allied nomenclature. In India some of the universities have started Agricultural Informatics as an Engineering Degree and among these are as per study as follows (refer table:3). 
TABLE I SAMPLE PROGRAM COMPONENTS OF MTECH, SHOBHIT UNIVERSITY, INDIA

\begin{tabular}{|c|c|}
\hline \multicolumn{2}{|c|}{$\begin{array}{l}\text { MTech (Agricultural Information Technology) } \\
\text { Shobhit University, Meerut, UP, India }\end{array}$} \\
\hline Semester-I & Semester-II \\
\hline $\begin{array}{l}\text { Introduction to Information Technology } \\
\text { Programming \& Programming Paradigms } \\
\text { Farm Sector Infrastructure } \\
\text { Agricultural Economics and Trade } \\
\text { Web Designing, Web Services, Web GIS and Internet } \\
\text { Applications } \\
\text { Agricultural \& Food Processing Technologies } \\
\text { Agricultural Production Systems Management } \\
\text { Technology Standards and Development Engineering } \\
\text { Project Work (Minor) \& Seminar: Delivery Platform } \\
\text { for e-Governance (Mobile Governance, Social Media) }\end{array}$ & $\begin{array}{l}\text { Database Technology and Applications } \\
\text { Information resources, Information Retrieval and Technical } \\
\text { Communication } \\
\text { Software Engineering and Quality Management } \\
\text { Quantitative Techniques \& Data Analytics \& Modeling } \\
\text { Agricultural Finance, Insurance and Agri-Business } \\
\text { Management } \\
\text { Agricultural Extension, Methods and tools of Communication } \\
\text { Block Chain Technology and its Application } \\
\text { Industry } 4.0 \text { Technology System and Application } \\
\text { Digital Marketing Technology \& System } \\
\text { Project (including Field Work) \& e-Governance Development: } \\
\text { Operations and Management } \\
\text { Industrial Training -8 Weeks Summer Training after Semester- } \\
\text { II }\end{array}$ \\
\hline Semester-III & Semester-IV \\
\hline $\begin{array}{l}\text { Data Communication and Computer Networks, } \\
\text { Information Security, Network Economy } \\
\text { Farm Health Management, Expert Systems and } \\
\text { Organic Agriculture } \\
\text { e-Governance, Cloud Computing, Standards, } \\
\text { Interoperability and Digital preservation } \\
\text { Agricultural Credit and Financial Inclusion } \\
\text { Elective I } \\
\text { Elective II } \\
\text { Elective III } \\
\text { Entrepreneur Development Programme in Agricultural } \\
\text { Service Delivery } \\
\text { Artificial Intelligence \& Machine Learning } \\
\text { Industrial Training - Project Evaluation }\end{array}$ & $\begin{array}{l}\text { Field Work and Dissertation } \\
\text { Seminar in Informatics and e-Governance } \\
\text { Viva Voce }\end{array}$ \\
\hline
\end{tabular}

TABLE II DEPICTED THE AVAILABLE PROGRAMS ON AGRO INFORMATICS AND THEIR NATURE

\begin{tabular}{|l|c|}
\hline \multicolumn{1}{|c|}{ Universities } & Types \\
\hline $\begin{array}{l}\text { Tamil Nadu Agricultural University, } \\
\text { Tamil Nadu, India }\end{array}$ & $\begin{array}{c}\text { Agricultural \& } \\
\text { Public }\end{array}$ \\
\hline Shobhit University, Uttar Pradesh, India & $\begin{array}{c}\text { Professional \& } \\
\text { Private }\end{array}$ \\
\hline Rai University, Gujarat, India & $\begin{array}{c}\text { Professional \& } \\
\text { Private }\end{array}$ \\
\hline $\begin{array}{l}\text { Anand Agricultural University, Gujarat, } \\
\text { India }\end{array}$ & $\begin{array}{c}\text { Agricultural \& } \\
\text { Public }\end{array}$ \\
\hline Integral University, Uttar Pradesh, India & $\begin{array}{c}\text { Professional \& } \\
\text { Private }\end{array}$ \\
\hline
\end{tabular}


TABLE III DEPICTED THE AVAILABLE PROGRAMS ON AGRO INFORMATICS IN FEW INSTITUTES

\begin{tabular}{|l|l|}
\hline \multicolumn{1}{|c|}{ Universities/ Institutes } & \multicolumn{1}{c|}{ Programs } \\
\hline $\begin{array}{l}\text { Tamil Nadu Agricultural } \\
\text { University, Coimbatore, Tamil } \\
\text { Nadu, India }\end{array}$ & $\begin{array}{l}\text { BTech } \\
\text { Agricultural Information } \\
\text { Technology }\end{array}$ \\
\hline $\begin{array}{l}\text { Centre for Agricultural } \\
\text { Informatics and E Governance } \\
\text { Research Studies } \\
\text { Shobhit University, Meerut, UP, } \\
\text { India }\end{array}$ & $\begin{array}{l}\text { MTech } \\
\text { Agricultural Informatics }\end{array}$ \\
\hline Anand Agricultural University, \\
Gujarat, India & MTech \\
& Agricultural Information \\
\hline
\end{tabular}

Another institute offers the Science program (with MSc) i.e.Dhirubhai Ambani Institute of Information and Communication Technology (A Deemed University), Gujarat, India with MSc-IT in Agriculture \& Rural Development program.

Agricultural Informatics programs at Bachelors with BSc degree not yet availed according to the study. However, there is a potentiality to offer such programs even with BS Degree. Here some are proposed in Table: 4.

\section{TABLE IV POSSIBLE ACADEMIC PROGRAMS ON} AGRICULTURAL INFORMATICS IN SCIENCES

\begin{tabular}{|l|l|}
\hline \multicolumn{1}{|c|}{ UG } & \multicolumn{1}{|c|}{ PG } \\
\hline BSc-Agricultural Informatics & MSc-Agricultural Informatics \\
BS- Agricultural Informatics & MS- Agricultural Informatics \\
BS by Research (Agricultural & MS by Research (Agricultural \\
Informatics) & Informatics) \\
BSc by Research (Agricultural & MSc by Research (Agricultural \\
Informatics) & Informatics) \\
\hline
\end{tabular}

Agricultural Informatics due to interdisciplinary programs requires higher mental growth and interdisciplinary knowledge and diverse skill sets. Hence based on such mature intellectual capital research-based degrees are also proposed at Bachelors level in Science streams. Further like Bachelors, Masters are also provided in Science stream in the same table. Whereas based on Engineering and Technological degree requirements, proposed possible programs are provided in Table: 5 .

TABLE V POSSIBLE ACADEMIC PROGRAMS ON AGRICULTURAL INFORMATICS IN TECHNOLOGIES

\begin{tabular}{|l|l|}
\hline \multicolumn{1}{|c|}{ UG } & \multicolumn{1}{|c|}{ PG } \\
\hline BTech- Agricultural Informatics & MTech- Agricultural \\
BS- Agricultural Informatics & Informatics \\
BTech by Research & MS- Agricultural Informatics \\
(Agricultural Informatics) & MTech by Research \\
BE by Research & (Agricultural Informatics) \\
(Agricultural Informatics) & ME by Research \\
\hline
\end{tabular}

TABLE VI POSSIBLE ACADEMIC PROGRAMS ON AGRICULTURAL INFORMATICS IN MANAGEMENT SCIENCES

\begin{tabular}{|l|l|}
\hline \multicolumn{1}{|c|}{ UG } & \multicolumn{1}{c|}{ PG } \\
\hline BBA & MBA \\
(Agricultural Informatics \& & (Agricultural Informatics \& \\
Management) & Management) \\
BBM- & MBM \\
BS-Management (Agricultural & (Agricultural Informatics \& \\
Informatics) & Management) \\
B.Mgt.(Agricultural Informatics) & MS-Management \\
B.Com(Agro Informatics\& & Agricultural Informatics) \\
Management) & M.Mgt. (Agricultural \\
& Informatics) \\
& M.Com (Agro Informatics \& \\
\hline
\end{tabular}

The common perception is that Agricultural Informatics is to be offered as Science/ Technology streams. However, there is potentiality to offer the branch even in Applied Arts within the concentration of the Public Administration and Rural Development. Some of the proposed programs are offered in Table: 7. Herewith. Whereas the Agricultural Informatics programs with the Management concentration is provided in the table: 6 . Based on nomenclature, the focus was with Commerce, Management and Business Administration Degrees.

TABLE VII POSSIBLE ACADEMIC PROGRAMS ON AGRICULTURAL INFORMATICS IN APPLIED ARTS

\begin{tabular}{|l|l|}
\hline \multicolumn{1}{|c|}{ UG } & \multicolumn{1}{c|}{ PG } \\
\hline & MA/MSc-Public \\
BA/BSc- Public Administration & Administration \\
(Agricultural Informatics) & (Agricultural Informatics) \\
BA/BSc-Rural Development & MA/MSc-Rural Development \\
(Agricultural Informatics) & (Agricultural Informatics) \\
& \\
\hline
\end{tabular}

Agricultural Informatics as an interdisciplinary program, should be offered at Research level with MPhil and $\mathrm{PhD}$ Degrees and some of them with science and engineering concentration is provided in Table: 8 herewith.

TABLE VIII POSSIBLE ACADEMIC PROGRAMS ON AGRICULTURAL INFORMATICS IN ACADEMIC RESEARCH LEVEL

\begin{tabular}{|l|l|}
\hline \multicolumn{1}{|c|}{ Research } & \multicolumn{1}{c|}{$\begin{array}{c}\text { Research } \\
\text { (Engience\& Management) }\end{array}$} \\
\hline MPhil (Science)-Agricultural & MPhil (Engineering)- \\
Informatics & Agricultural Informatics \\
MPhil (Management)- & MPhil (Technology)- \\
Agricultural Informatics & Agricultural Informatics \\
PhD (Science)- Agricultural & PhD (Engineering)- \\
Informatics & Agricultural Informatics \\
PhD (Management)- & PhD (Technology)- \\
Agricultural Informatics & Agricultural Informatics \\
\hline
\end{tabular}


TABLE IX POSSIBLE ACADEMIC PROGRAMS ON AGRICULTURAL INFORMATICS IN PROFESSIONAL RESEARCH LEVEL

\begin{tabular}{|l|}
\multicolumn{1}{|c|}{ Professional Doctorate } \\
(Work Experience/ Publications based)
\end{tabular}

In the recent past, the nature of Research degrees become changed and many other new methods have been imported in awarding degrees and among these by publications can be considered as an important one. In this, instead of an academic thesis, scientific publications with quality and quantity can be provided in the form of a thesis. Here work experiences and research experiences in the form of evidence considered as a form of merit. And in the context of Agricultural Informatics such degrees are proposed. Even scientific higher doctorates (viz. DSc), professional doctorates (may be general or higher/post-doctoral) can also be offered on Agricultural Informatics or on allied subjects.

Hence due to wide variety of potentiality Agricultural Informatics programs may be offered beyond MSc, BTech, MTech as full-fledged degrees mentioned above. The Agricultural Informatics will be also helpful in few other allied and indirect activities such as

1. Agricultural Industries and Companies

2. Agricultural research-based services,

3. Scientific organizations development in the fields

4. Development in Educational Institutes on Agricultural Informatics or Agriculture or allied fields.

Though governments of different countries have taken initiatives for the modernization of educational systems but still more initiatives are essential and different programs (with various levels) on different nomenclature on Agricultural Informatics may be offered as a full-fledged manner.

\section{SUGGESTIONS AND POTENTIALITIES}

Agricultural Informatics as helps directly and indirectly in different cultivation and farming activities in including pre and post agriculture in corps, plants, seed, etc with the animals, marketing of agricultural; so it is better to go with the following (as much as possible)

1. Agricultural Informatics needs a good amount of budget in technological setup, operation, further technologies implementation and post installation services, etc.
2. It is required that manpower should be the holder of interdisciplinary knowledge, skill sets. So, here healthy, scientific degrees, proper educational opportunities should be provided.

3. Agricultural Informatics programs even may be offered in specializations of emerging technologies such as viz. IoT, Cloud, Big Data, Robotics and AI, etc.

4. In addition to existing Agricultural Informatics, the full degrees or merged nomenclature may be offered in subjects such as Agro ICT, Agricultural Information Technology, Smart Agriculture, Digital Agriculture, etc at UG, PG, Research levels.

5. Professional Doctorates, Higher Doctorates, Publication by Doctorates can be offered on Agricultural Informatics or allied subjects to the existing experts or interested scholars and fellows.

6. As Agricultural Informatics is practice based so there should be proper Industrial tie-ups as well as collaboration with Agricultural farms and Companies. Even better collaboration is expected with IT Companies for higher delivery.

7. IoT, Cloud Computing, Data Analytics, HCI, Robotics and Cloud are very important components and needed in contemporary smarter agriculture; so, in the existing or full-fledged degrees on Agricultural Informatics such components and courses need to include.

\section{CONCLUSION}

Educational systems are internationally changing, and various modern skill-based subjects become an integral part of modern universities and educational institutes. Interdisciplinary knowledge creation is noticeable and as far as Agricultural Informatics is concerned, this trend is eye catching. Sustainable agricultural systems have been started in many countries to bring smarter and healthy Agricultural systems.

In this context Agricultural Informatics is important with management, tools, emerging technologies such as IoT, Big Data, Cloud, etc. As, Agricultural Informatics is helpful in the activities of agro in the sectors such as water, climate, soil, crop, plants, animals, therefore this is a high time to introduce Agricultural Informatics and allied programs with solid planning and educational policies. In this context, proper academic and industrial collaboration are needed. With the initiation of the better Agricultural Informatics practice the associates and stakeholders of Agricultural Informatics can be benefited viz. agro fields, cultivating items, postproduction areas, firms, trusts, companies etc. Ultimately with the promotion of the Agricultural Informatics in academia Smart Agriculture, Sustainable Development are possible in a different context. Agricultural Informatics degrees can be offered in short term courses and other than degrees viz. Certificate, Diploma, Advanced Diploma in different level of education. 


\section{REFERENCES}

[1] Abbasi, A. Z., Islam, N., \& Shaikh, Z. A., "A review of wireless sensors and networks' applications in agriculture," Computer Standards \& Interfaces, Vol. 36, No. 2, pp. 263-270, 2014

[2] Adão, T. et.al., "Hyperspectral imaging: A review on UAV-based sensors, data processing and applications for agriculture and forestry,”. Remote Sensing, Vol. 9, No. 11, pp. 1110-1120, 2017.

[3] Adetunji, K. E., \& Joseph, M. K., "Development of a Cloud-based Monitoring System using 4duino: Applications in Agriculture”. In 2018 International Conference on Advances in Big Data, Computing and Data Communication Systems (icABCD) (pp. 4849-4854), 2018

[4] Ahmad, T., Ahmad, S., \& Jamshed, M., "A knowledge based Indian agriculture: With cloud ERP arrangement”. In 2015 International Conference on Green Computing and Internet of Things (ICGCIoT), pp. 333-340, October, 2015

[5] Aubert, B. A., Schroeder, A., \& Grimaudo, J. "IT as enabler of sustainable farming: An empirical analysis of farmers' adoption decision of precision agriculture technology," Decision support systems, Vol.54 , No. 1, pp. 510-520, 2012

[6] Babu, S. M., Lakshmi, A. J., \& Rao, B. T. "A study on cloud based Internet of Things: CloudIoT”. In 2015 global conference on communication technologies (GCCT) (pp. 60-65). IEEE, April, 2015

[7] Balamurugan, S., Divyabharathi, N., Jayashruthi, K., Bowiya, M., Shermy, R. P., \& Shanker, R, "Internet of agriculture: Applying IoT to improve food and farming technology", International Research Journal of Engineering and Technology (IRJET), Vol. 3, No. 10, pp.713-719, 2016

[8] Bauckhage, C., \& Kersting, K, "Data mining and pattern recognition in agriculture," KI-Künstliche Intelligenz, Vol.27 , No. 4, pp. 313324, 2013

[9] Channe, H., Kothari, S., \& Kadam, D, "Multidisciplinary model for smart agriculture using internet-of-things (IoT), sensors, cloudcomputing, mobile-computing \& big-data analysis," Int. J. Computer Technology \& Applications, Vol. 6, No. 3, pp. 374-382, 2015

[10] Gill, S. S., Chana, I., \& Buyya, R., "IoT based agriculture as a cloud and big data service: the beginning of digital India," Journal of Organizational and End User Computing (JOEUC), Vol. 29, No. 4, pp.1-23, 2017

[11] Gómez-Chabla, R., Real-Avilés, K., Morán, C., Grijalva, P., \& Recalde, T. "IoT Applications in Agriculture: A Systematic Literature Review". In 2nd International Conference on ICTs in Agronomy and Environment, pp. 68-76, 2009

[12] Goraya, M. S., \& Kaur, "H. Cloud computing in agriculture". HCTL Open International Journal of Technology Innovations and Research (IJTIR), Vol. 16, pp. 2321-1814, 2015

[13] Guardo, E., Di Stefano, A., La Corte, A., Sapienza, M., \& Scatà, M., "A fog computing-based iot framework for precision agriculture", Journal of Internet Technology, Vol . 19,No. 5, pp. 1401-1411, 2018

[14] Kamble, S. S., Gunasekaran, A., \& Gawankar, S. A., "Achieving sustainable performance in a data-driven agriculture supply chain: A review for research and applications," International Journal of Production Economics, Vol. 219, pp. 179-194, 2020

[15] Kajol, R., \& Akshay, K. K., Automated Agricultural Field Analysis and Monitoring System Using IOT. International Journal of Information Engineering and Electronic Business, Vol.11, No.2, 2018

[16] Khattab, A., Abdelgawad, A., \& Yelmarthi, K. Design and implementation of a cloud-based IoT scheme for precision agriculture. In 2016 28th International Conference on Microelectronics, pp. 201-204, IEEE, December, 2016

[17] Liu, S., Guo, L., Webb, H., Ya, X., \& Chang, X. Internet of Things monitoring system of modern eco-agriculture based on cloud computing. IEEE Access, Vol. 7, 37050-37058, 2019

[18] Manos, B., Polman, N., \& Viaggi, D. "Agricultural and environmental informatics, governance and management: Emerging research applications," Z. Andreopoulou (Ed.). IGI Global (701 E. Chocolate Avenue, Hershey, Pennsylvania, 17033, USA, 2011

[19] Muangprathub, J., Boonnam, N., Kajornkasirat, S., Lekbangpong, N., Wanichsombat, A., \& Nillaor, P, "IoT and agriculture data analysis for smart farm". Computers and electronics in agriculture, Vol. 156, pp. 467-474, 2019.
[20] Na, A., \& Isaac, W, Developing a human-centric agricultural model in the IoT environment. In 2016 International Conference on Internet of Things and Applications (IOTA) pp. 292-297, IEEE, January, 2016

[21] Nandyala, C. S., \& Kim, H. K., "Green IoT agriculture and healthcare application (GAHA)”. International Journal of Smart Home, Vol. 10, No.4, pp. 289-300, 2016

[22] Othman, M. F., \& Shazali, K, "Wireless sensor network applications: A study in environment monitoring system," Procedia Engineering, Vol. 41, pp. 1204-1210, 2012

[23] Ozdogan, B., Gacar, A., \& Aktas, H., Digital agriculture practices in the context of agriculture 4.0. Journal of Economics Finance and Accounting, Vol. 4, No. 2, pp. 186-193, 2017

[24] Pau1, Prantosh Kumar Minakshi Ghosh, Dipak Chaterjee, "Information Systems \& Networks (ISN): Emphasizing Agricultural Information Networks with a case Study of AGRIS”.Scholars Journal of Agriculture and Veterinary Sciences, Vol. 1,No. 1, pp. 38-41, 2014

[25] Paul, Prantosh Kumar, "Information and Knowledge Requirement for Farming and Agriculture Domain”.International Journal of Soft Computing Bio Informatics, Vol. 4, No. 2, pp. 80-84, 2013

[26] Paul, Prantosh Kumar etal, "Agricultural Problems in India requiring solution through Agricultural Information Systems: Problems and Prospects in Developing Countries," International Journal of Information Science and Computing,Vol. 2, No.1, pp. 33-40.

[27] Paul, Prantosh Kumar etal. "Cloud Computing and Virtualization in Agricultural Space: A Knowledge Survey”. Palgo Journal of Agriculture, Vol. 4, No. 2, pp.202-206, 2016

[28] Paul, Prantosh Kumar etal, "Information and Communication Technology and Information: their role in Tea Cultivation and Marketing in the context of Developing Countries-A Theoretical Approach". Current Trends in Biotechnology and Chemical Research,Vol. 5, No. 2, pp. 55-161, 2015

[29] Rezník, T., Charvát, K., Lukas, V., Charvát Jr, K., Horáková, Š., \& Kepka, M., "Open data model for (precision) agriculture applications and agricultural pollution monitoring". In EnviroInfo and ICT for Sustainability 2015. Atlantis Press, Sept. 2015

[30] TongKe, F. "Smart agriculture based on cloud computing and IOT," Journal of Convergence Information Technology, Vol. 8, No. 2, pp. 210-216, 2013

[31] Tsekouropoulos, G., Andreopoulou, Z., Koliouska, C., Koutroumanidis, T., \& Batzios, C, "Internet functions in marketing: multicriteria ranking of agricultural SMEs websites in Greece" Agrárinformatika/journal of agricultural informatics, Vol. 4, No. 2, pp. 22-36, 2013.

[32] Zamora-Izquierdo, M. A., Santa, J., Martínez, J. A., Martínez, V., \& Skarmeta, A. F. "Smart farming IoT platform based on edge and cloud computing”. Biosystems engineering, Vol. 177, pp. 4-17, 2013. 